\title{
The Effect of Supervisory Board Size on Corporate-Level Strategies-Evidence from Polish Public Companies
}

\author{
Zbigniew Matyjas
}

\begin{abstract}
This study examines the impact of supervisory board size on corporate-level strategies of Polish listed companies. The study uses data of 201 companies whose values were listed at the end of the year 2011 at the Warsaw Stock Exchange. After using two different multiple regression models the results have showed that the size of the supervisory board has rather strong, although negative effect on two different corporate-level strategies: diversification and internationalization.
\end{abstract}

Index Terms-Corporate-level strategy, diversification, internationalization, Poland, supervisory board.

\section{INTRODUCTION}

The role of the board of directors and its impact on corporate-level strategies is quite well understood and described in the literature of strategic management. There has been reached an agreement that boards play important role in the agency theory in order to solve many problems between shareholders and management systems. Many prior research articles have examined that issue [1], although they were usually based on American (or British) examples, and on the same model of corporate governance.

On the European continent there are at present two different types of board models: a one-tier model with the common board of directors, and two-tier model with the separation of two different functions: management and control. During the transition from socialism to capitalism systems in the 1990s the two-tier board model in Poland have been restored [2] with two separate boards: a management board and a supervisory board. That process in conjunction with mass privatization system in Poland has brought about a certain effect in the form of, inter alia, a substantial increase in the degree of concentration of ownership in companies, particularly in comparison to that present in developed countries [3].

Hence, the purpose of this study is to examine the impact of the board size of Polish companies (listed on the Warsaw Stock Exchange) on their corporate-level strategies. Given the significant differences in the development of the Polish capital market, you can also expect differences in the results of the proposed research in comparison to similar projects undertaken in other countries.

The additional aim of the study is the desire to reduce the gap in terms of empirical studies on the example of Central

Manuscript received March 5, 2014; revised May 4, 2014. This work was supported by the Polish National Science Centre under Grant N N115 401340.

Zbigniew Matyjas is with the Faculty of Management, University of Lodz, Lodz, 90-237 Poland (e-mail: zmatyjas@uni.lodz.pl).
European markets, especially Polish one, as there is, in principle, lack of research articles form that part of Europe in recent management literature [4].

\section{LITERATURE REVIEW}

In recent years there have been undertaken many research studies whose aim was to examine the potential links between the issues in two different fields of knowledge: corporate governance and strategic management. The first studies within that area have appeared as early as in the 1970s [5], [6], then the interest in this subject has gradually grown. This increase in interests by, visible in the coming years, it is now particularly evident. This is no longer the first timid attempts to look for relationships between corporate governance of strategic management, at this stage the number and variety of paths of research is impressive.

This is true both in the case of American research, as well as increasingly emerging examples from many other countries. Yoshikawa and Phan [7] have examined the effect of ownership and capital structure on board composition and diversification strategies at the example of Japanese market, while David et al. [8] continued with similar effort, although this time their focus was on ownership structures of Japanese corporations. Chen et al. [9] have examined links between board composition and diversification strategies in Australia.

There have been also undertaken a huge body of American research recently, both with typical examination of some special issues between several strategic issues and corporate governance [10], [11], as well as rather unusual approach, like thinking from strategic cognitive perspective [12], which could ultimately lead to latest rankings of US boards and their implications on stockholders [13]. Other important subjects which were analyzed were among others the capability for strategic change at the level of the boards alone, as well as the whole TMTs [14]-[16]. However there is still much interest in exploring agency theory issues [17], [18]. To just quickly recapitulate such an impressive body of research I must admit, that the results of all of these research articles are at least mixed. As Dalton et al. [19] stated, evidence what drives board effectiveness is so mixed that they recommend adopting much more sensitive approach in future studies, such as taking into account the differences between the various countries in which the research may be done in the future

It is of particular importance in the case of current research approach. Taken into account the specificity of the Polish two-tier board model, one can expect much more diverse outcomes compared to the results within one-tier board model. Within two-tier board model there is a strictly defined 
difference between the two types of boards. One of them, the management board, is responsible for managing the whole company. Under such circumstances all of strategic decisions are by definition undertaken by the members of the management board, they are responsible for both formulating and implementing strategies within their companies. The second board, which is called the supervisory board, is responsible for day-to-day supervision in all the areas of company's activity. As Bohdanowicz [2] noted, the responsibilities of supervisory board can be broadened by shareholders in Poland, particularly through provisions contained in the articles of association. So it is common under Polish conditions that the members of supervisory boards in leading Polish companies (usually listed on the stock exchange) can also enter into much more day-to-day contacts with the member of the management board in order to help the managers with all of their strategic responsibilities (like strategic plans, annual budgets, sales or purchasing real estate's etc.).

Such a two-tier model is typical in Central Europe, particularly in German-speaking area, so it is not solely related with Polish experiences. But taking into account the special role of previous privatization processes, which weren't typical for Western European countries, a two-tier model can be perceived as even more specific in Polish conditions.

\section{HYPOTHESES}

Taking into considerations the earlier observations it is possible to expect at least some hypotheses regarding the results of the current research. The main aim of this article is to examine the potential connections between corporate-level strategies and board structures of Polish listed companies. The term corporate-level strategy was so broad that it had to be adjusted in order to meet the research requirements. So I decided to simplify it to just two possible strategies: diversification and internationalization, while the structure of the supervisory board I understood just its size.

That leads to two different types of hypotheses:

Hypothesis 1: The number of supervisory board members is positively associated with the degree of diversification of the company.

Hypothesis 2: The number of supervisory board members is positively associated with the scope of internationalization of the company.

\section{DATA AND METHODS}

\section{A. Sample}

The primary objective of the study is to verify the impact of supervisory board size on the degree of diversification and internationalization of Polish companies. Data for this study were gathered from all Polish public companies whose values were listed at the end of the year 2011 on the Warsaw Stock Exchange (main market). Financial and commercial companies were excluded from the data due to preliminary assumptions of the study (difficulties in adapting particular measures of diversification to meet the needs of such types of businesses). Data were collected from two different databases: the Amadeus and Datastream databases (companies listed on the Stock Exchange), as well as the consolidated annual reports or reports of individual companies, if the company did not prepare consolidated reports (both of them were hand-collected) for assessing the level of diversification and internationalization (they were not present in neither of databases).

Given the above assumptions the sample comprises 201 companies.

\section{B. Variables}

The analyzed variables were divided into three basic groups: characterizing the size of the supervisory boards of companies, strategic variables describing companies' diversification [20]-[22], internationalization [19], [23], [24], and the control variables describing the size of the companies and its profitability. List of all analyzed variables can be found in Table I.

TABLE I: VARIABLES USED IN RESEARCH

\begin{tabular}{cl} 
& TABLE I: VARIABLES USED IN RESEARCH \\
\hline \hline Acronym & \multicolumn{1}{c}{ Description of the Variable } \\
\hline BN_11 & Supervisory board size \\
HI_11 & Diversification strategy measured as Herfindhal index \\
FR\%_11 & Internationalization strategy (\% of total revenues) \\
ROA_11 & Return on assets \\
ROS_11 & Return on sales \\
AO_11 & Overall assets (measured as natural logarithm) \\
Rev_11 & Overall revenues (measured as natural logarithm) \\
\hline \hline
\end{tabular}

\section{Methods}

The study was conducted with the use of a multiple regression model. The models build for the estimation of the impact of supervisory board size on diversification and internationalization strategies of companies assumed that:

Model 1:

Diversification strategy

$$
\begin{aligned}
& \mathrm{Y}\left(\mathrm{HI}_{-} 11\right)=\beta_{0}+\beta_{1} \mathrm{BN}_{-} 11+\beta_{2} \mathrm{ROA}_{-} 11+ \\
& \beta_{3} \mathrm{ROS}_{-} 11+\beta_{4} \mathrm{AO} \_11+\beta_{5} \mathrm{Re}_{-} 11+\varepsilon
\end{aligned}
$$

Model 2:

Internationalization strategy

$$
\begin{aligned}
& \mathrm{Y}\left(\mathrm{FR} \%{ }_{-} 11\right)=\beta_{0}+\beta_{1} \mathrm{BN}_{-} 11+\beta_{2} \mathrm{ROA}_{-} 11+ \\
& \beta_{3} \mathrm{ROS}_{-} 11+\beta_{4} \mathrm{AO}_{-} 11+\beta_{5} \operatorname{Re} \mathrm{v}_{-} 11+\varepsilon
\end{aligned}
$$

where:

- Y(HI_11) - the degree of diversification of company (measured as Herfindahl index)

- $\quad \mathrm{Y}(\mathrm{FR} \%$ _11) - the degree of internationalization of company (measured as $\%$ of foreign revenues to total revenues)

- $\quad \beta_{1} \mathrm{BN} \_11$ - supervisory board size of company (natural number)

- $\quad \beta_{2}$ ROA_11-ROA of company 
- $\quad \beta_{3}$ ROS_11-ROS of company

- $\quad \beta_{4}$ AO_11 - overall assets of company (measured as natural logarithm)

- $\quad \beta_{5}$ Rev_11 - revenues of company (measured as natural logarithm)

- $\quad \beta_{0}-$ Constant

\section{RESULTS}

\section{A. Descriptive Statistics}

Table II gives the mean, standard deviation, minimum and maximum values of the variables across all firms in the sample. Table III gives the correlation matrix between the variables.

TABLE II: DESCRIPTIVE STATISTICS

\begin{tabular}{ccccc}
\hline \hline Variable & Mean & Min & Max & SD \\
\hline BN_11 & 5,88 & 5,00 & 13,00 & 1,50 \\
HI_11 & 0,58 & 0,19 & 1,00 & 0,23 \\
\hline \hline FR\%_11 & 0,21 & 0,00 & 0,98 & 0,23 \\
\hline \hline ROA_11 & 1,89 & $-88,50$ & 52,64 & 13,94 \\
\hline \hline ROS_11 & $-5,92$ & $-1135,00$ & 23,24 & 71,66 \\
\hline \hline AO_11 & 4,50 & $-0,89$ & 10,98 & 2,20 \\
\hline \hline Rev_11 & 4,09 & $-6,91$ & 11,59 & 2,64 \\
\hline \hline
\end{tabular}

TABLE III: CORRELATION MATRIX

\begin{tabular}{|c|c|c|c|c|c|c|c|}
\hline Variable & ROA_11 & ROS_11 & AO_11 & Rev_11 & BN_11 & HI_11 & FR\%_11 \\
\hline ROA_11 & 1,00 & & & & & & \\
\hline ROS_11 & $0,62^{\text {***k }}$ & 1,00 & & & & & \\
\hline AO_11 & 0,08 & 0,02 & 1,00 & & & & \\
\hline Rev_11 & $0,13^{*}$ & $-0,03$ & $0,89^{\text {**** }}$ & 1,00 & & & \\
\hline BN_11 & $-0,00$ & $-0,10$ & $0,58^{* * * *}$ & $0,47^{\text {*** }}$ & 1,00 & & \\
\hline HI_11 & 0,04 & 0,01 & $-0,12$ & $-0,09$ & 0,05 & 1,00 & \\
\hline FR\%_11 & $-0,02$ & $-0,17^{* *}$ & 0,07 & $0,15^{* *}$ & $-0,08$ & $-0,07$ & 1,00 \\
\hline
\end{tabular}

\section{B. Model 1}

Results for model 1 are presented in Table IV. On the basis of these results we can see some confirmation for the proposed Hypothesis 1 that the size of the supervisory board has some impact for the diversification strategies undertaken by companies. Although one can find it interesting that these results mean that the impact is not positive, but clearly negative. This influence can be perceived as quite strong, with the statistical significance level $\alpha=0.05$. This negative result means - the higher the number of the supervisory board the stronger the possibility to achieve higher level of Herfindahl index, which means that the overall level of diversification is decreasing.

Besides this variable (the size of the supervisory board) the other variables are none significant with one weak exception - the overall assets of the company has slightly negative result for the level of Herfindahl index (with $\alpha=0.1$ ). That means that to some extent the higher the scale of the company (in terms of total assets) the higher the level of diversification. The three other variables are no significant at all. The overall coefficient level for this model is rather weak, with low values of $R^{2}$ and Adjusted $R^{2}$.

\section{Model 2}

Results for model 2 are presented in Table V. These results are much more promising in terms of the significance levels for almost all of the variables used in the model. First of all the confirmation for hypothesis 2 is at least as strong as with model 1 (exactly the same levels of t-statistics). That means that the size of the supervisory board in Polish listed companies is significant (with $\alpha=0.05$ ) for both strategy of diversification and internationalization. And besides the other (minus) sign the board size has the same negative effect on companies' level of internationalization.
As can be clearly observed from the results of table 5, the other variables are much more useful with this model of regression. Not only the size of the supervisory board is statistically significant (at $\alpha=0.05$ level) for the level of internationalization, but also two other variables: both ROS and the scale of company (measured by total revenues) at $\alpha=$ 0.05 . In addition to that the overall coefficient level for this model is a bit better, with higher values of $R^{2}$ and Adjusted $R^{2}$.

TABLE IV: RESULTS FOR MODEL 1 - DIVERSIFICATION STRATEGY

\begin{tabular}{cccccccc}
\hline \hline Variable & $N$ & $R$ & $R^{2}$ & Adj. $R^{2}$ & $F$ & $\beta$ & $t$ \\
\hline$\beta_{0}$ & & & & & & $0,582^{* * * *}$ & 8,06 \\
ROA_11 & & & & & & 0,001 & 0,44 \\
ROS_11 & \multirow{2}{*}{186} & \multirow{2}{*}{0,206} & \multirow{2}{*}{0,043} & \multirow{2}{*}{0,017} & 1,633 & 0,009 & 0,13 \\
AO_11 & & & & & & $-0,046^{*}$ & $-1,92$ \\
Rev_11 & & & & & & 0,015 & 0,69 \\
BN_11 & & & & & & $0,030^{* * *}$ & 2,19 \\
\hline
\end{tabular}

Significant at: * 10\%** 5\%***1\%

TABLE V: RESULTS FOR MODEL 2 - INTERNATIONALIZATION STRATEGY

\begin{tabular}{cccccccc}
\hline \hline Variable & $N$ & $R$ & $R^{2}$ & Adj. $R^{2}$ & $F$ & $\beta$ & $t$ \\
\hline$\beta_{0}$ & & & & & & $0,235^{* * * *}$ & 3,18 \\
ROA_11 & & & & & & 0,002 & 0,88 \\
ROS_11 & \multirow{2}{*}{0,301} & 0,090 & 0,065 & 3,537 & $-0,171^{* * *}$ & $-2,36$ \\
AO_11 & & & & & & $-0,019$ & $-0,76$ \\
Rev_11 & & & & & & $0,047^{* *}$ & 2,08 \\
BN_11 & & & & & $-0,028^{* * *}$ & $-2,01$ \\
\hline \hline
\end{tabular}

Significant at: *10\% ** 5\%***1\%

\section{DISCUSSION AND CONCLUSIONS}

Overall I found that the data provide support for both of my hypotheses in the research model. It means that, at least to some extent, one can expect that the size of the supervisory 
board of Polish listed companies is statistically proper indicator of levels of their commitment to diversification and internationalization strategies. However, what can be surprising, the impact of the supervisory board size is negative for both of these strategies, which means that the less populated supervisory boards are more willing to accept (we can think in terms of merely acceptance for the supervisory board) more aggressive and risky strategies like diversification or internationalization.

The explanation to that phenomenon might have been caused by the historical processes of Polish quick privatization. These observations are quite similar to the previous research [25] of the surprisingly low level of correlation between the scale of the listed company itself and its level of diversification and internationalization. According to the results of cited previous research, the only possible explanation was with the nature of privatization processes in Poland.

Further research in this area seems to be appropriate, with particular emphasis on Polish (and other Central and Eastern Europe markets) specificity. The development of emerging economies often took place in a completely different way from established routines of many developed economies. And it can also affect the results of similar studies. However further studies in this area should take into account somewhat broader spectrum of the analyzed variables and the longer time period - though in the case of Poland it is difficult to go beyond 10 years (due to unavailability of data).

\section{REFERENCES}

[1] J. Jeżak, Ład korporacyjny. Doświadczenia Światowe Oraz Kierunki Rozwoju, Warszawa, Poland: Wydawnictwo C.H. Beck, 2010.

[2] L. Bohdanowicz. (July 2012). Ownership Structure and Female Directors on Two-Tier Boards: Evidence from Polish Listed Companies. SSRN [Online]. Available: http://ssrn.com/abstract $=2117870$

[3] J. Jeżak, L. Bohdanowicz, and Z. Matyjas, "Corporate governance, ownership structure, and corporate performance: Evidence from Polish listed companies," in Proc. Conf. on Marketing Innovation and Strategic Management of Transition from OEM to OSM, Guangzhou, 2009, pp. 40-50.

[4] Z. Matyjas, "Firm and industry effects on company performance: Evidence from polish listed companies," in Proc. 9th EBES Conference, Rome, Italy, 2013, pp. 2356-2366.

[5] M. C. Jensen and W. H. Meckling, "Theory of the firm: Managerial behaviour, agency costs, and ownership structure," Journal of Financial Economics, vol. 3, pp. 305-360, October 1976.

[6] J. Pfeffer and G. R. Salancik, The External Control of Organizations: A Resource Dependence Perspective, New York: Harper \& Row, 1978.

[7] T. Yoshikawa and P. H. Phan, "The effects of ownership and capital structure on board composition and strategic diversification in japanese corporations," Corporate Governance: An International Review, vol. 13, pp. 303-312, March 2005.

[8] P. David, J. P. O'Brien, T. Yoshikawa, and A. Delios, "Do shareholders or stakeholders appropriate the rents from corporate diversification? The influence of ownership structure," Academy of Management Journal, vol. 53, pp. 636-654, June 2010.

[9] R. Chen, M. C. Dyball, and S. Wright, "The link between board composition and corporate diversification in Australian corporations," Corporate Governance: An International Review, vol. 17, pp. 208-223, March 2009.
[10] Y. Y. Kor, "Direct and interaction effects of top management team and board composition on R\&D investment strategy," Strategic Management Journal, vol. 27, pp. 1081-1099, November 2006.

[11] L. Tihanyi, R. A. Johnson, R. E. Hoskisson, and M. A. Hitt, "Institutional ownership differences and international diversification: The effects of boards of directors and technological opportunity," Academy of Management Journal, vol. 46, pp. 195-211, April 2003.

[12] V. Rindova, "What corporate boards have to do with strategy: A Cognitive perspective," Journal of Management Studies, vol. 36, pp. 953-975, December 1999.

[13] J. L. Johnson, A. E. Ellstrand, D. R. Dalton, and C. M. Dalton, "The influence of the financial press on stockholder wealth: The case of corporate governance," Strategic Management Journal, vol. 26, pp. 461-471, May 2005.

[14] K. Bongjin, L. B. Burns, and J. E. Prescott, "The strategic role of the board: The impact of board structure on top management team strategic action capability," Corporate Governance: An International Review, vol. 17, pp. 728-743, November 2009.

[15] B. R. Golden and E. J. Zajac, "When will boards influence strategy? Inclination $\times$ Power $=$ Strategic Change," Strategic Management Journal, vol. 22, pp. 1087-1111, December 2001.

[16] T. J. Quigley and D. C. Hambrick, "When the former CEO stays on as board chair: Effects on successor discretion, strategic change, and performance," Strategic Management Journal, vol. 33, pp. 834-859, July 2012.

[17] M. A. Geletkanycz and B. K. Boyd, "CEO Outside Directorships and Firm Performance: A Reconciliation of Agency and Embeddedness Views," Academy of Management Journal, vol. 54, pp. 335-352, April 2011.

[18] M. Jensen and E. J. Zajac, "Corporate elites and corporate strategy: How demographic preferences and structural position shape the scope of the firm," Strategic Management Journal, vol. 25, pp. 507-524, June 2004.

[19] D. M. Reeb, C. Y. Kwok, and Y. Baek, "Systematic risk of the multinational corporation," Journal of International Business Studies, vol. 29, pp. 263-279, June 1998.

[20] R. Amit and J. Livnat, "A concept of conglomerate diversification," Journal of Management, vol. 14, pp. 593-604, December 1988.

[21] H. P. Bowen and M. F. Wiersema, "Foreign-Based competition and corporate diversification strategy," Strategic Management Journal, vol. 26, pp. 1153-1171, December 2005.

[22] S. P. Raghunathan, "A refinement of the entropy measure of firm diversification: toward definitional and computational accuracy," Journal of Management, vol. 21, pp. 989-1002, October 1995.

[23] A. Duru and D. M. Reeb, "Geographic and industrial corporate diversification: The level and structure of executive compensation," Journal of Accounting, Auditing and Finance, vol. 17, pp. 1-24, January 2002.

[24] D. Sullivan, "Measuring the degree of internationalization of a firm," Journal of International Business Studies, vol. 25, pp. 325-342, June 1994.

[25] J. Jeżak, Struktury Własności Polskich Spółek Publicznych a Ich Strategie Rozwoju, Łódź, Poland: Wydawnictwo Uniwersytetu Łódzkiego, 2010.

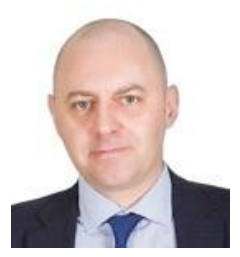

Zbigniew Matyjas received his M.Sc. and Ph.D degrees in management from the University of Lodz in 1996 and 2004, respectively.

Currently he is with the Faculty of Management, University of Lodz, Poland as an assistant professor. He has been working as a consultant and trainer with many leading Polish corporations within development of strategies and implementation of the balanced scorecard. He has completed a number of specialized foreign training courses, e.g. at the University of Maryland (USA), and University of Texas at Austin (USA). His research interests include competitive dynamics, competitive strategies, strategic analyses, and economics of strategy. Dr. Matyjas is also a member of EBES. 